\title{
Fundamentos da homeopatia e sua aplicação na clínica de cães e gatos*
}

\author{
SUZANA DE SOUZA NODARI
}

\author{
João Carlos Gonzales (Orientador - UFRGS)
}

Banca: Hilton Machado Magalhães (UFSM), José Maria Wiest (UFRGS), Maria Lúcia Scroferneker (UFRGS)

O presente trabalho disserta sobre a medicina homeopática na veterinária. Através de estudo exploratório bibliográfico de síntese oferece um ordenamento do conhecimento homeopático e está estruturado em três grandes tópicos. Inicia com um breve relato histórico da vida de Samuel Hahnemann e do desenvolvimento da homeopatia. Em seguida, apresenta os principais fundamentos filosóficos e científicos da medicina homeopática, que são: o pensamento vitalista, o princípio dos semelhantes, a experimentação no homem são, o medicamento diluído e dinamizado, o medicamento único, a individualização do doente e sua totalidade sintomática. Apresenta, ainda, a concepção homeopática de doença. Por fim, descreve a conduta homeopática na clínica de cães e gatos. Nesse capítulo, inicia com a descrição do principal livro homeopático - o Organon - e descreve as outras duas ferramentas principais de trabalho do exercício da medicina homeopática: o repertório e as matérias médicas. Na descrição da consulta homeopática, inicia considerando sobre o observador médico e apresenta os diferentes estágios dessa prática, da resenha e história clínica até a avaliação da evolução do quadro do paciente, passando pelos exames clínico e complementares, análise do caso, escolha do medicamento e prescrição. Conclui sintetizando os aspectos principais dessa medicina.

Descritores: homeopatia, homeopatia veterinária, fundamentos homeopáticos.

Apresentada: 19 dezembro 2002

* Dissertação de Mestrado no 341 (Especialidade: Medicina Veterinária Preventiva). 98f. Programa de Pós-Graduação em Ciências Veterinárias da Faculdade de Veterinária - UFRGS, Porto Alegre/RS. CORRESPONDÊNCIA: S. S. Nodari [nodari@cpovo.net]. 


\title{
Homeopathic fundamentals and its application in the clinic of dogs and cats**
}

\author{
SUZANA DE SOUZA NODARI
}

João Carlos Gonzales (Adviser - UFRGS)

Committee: Hilton Machado Magalhães (UFSM), José Maria Wiest (UFRGS), Maria Lúcia Scroferneker (UFRGS)

The present work examines the homeopathic medicine in veterinary. Through synthetic bibliographic exploratory study, it offers an organization of the homeopathic knowledge, structured in three big topics. It starts with a brief historic report on Samuel Hahnemann's life and the development of homeopathy, followed by the presentation of the main philosophical and scientific fundamentals of the homeopathic medicine, which are: the vitalist thinking, the principle of similitude, the experimentation with healthy human beings, the diluted and dynamized remedy, the single remedy, the patient's individualization and the totality of symptoms. This study also presents the homeopathic concept of illness. Finally, it describes the homeopathic procedures in the clinic of dogs and cats. This chapter starts with a description of the most important homeopathic book - the Organon - and describes the two other main tools for the homeopathic medicine: the repertory and the materias medicas. In describing the homeopathic appointment, it starts considering the doctor observer and presents the different stages of this practice, the review and clinic history, until the assessment of the evolution of the patient's condition, the clinic and additional exams, case analysis, choice of remedy and prescription. The study is concluded with a synthesis of the main aspects of this medicine.

Key words: homeopathy, veterinary homeopathy, homeopathic fundamentals. 